\title{
PREVALENCE OF CRYPTOSPORIDIOSIS IN HIV/AIDS PATIENTS IN A TERTIARY CARE HOSPITAL IN WEST BENGAL
}

\author{
Sangita Saha1, Mohua Bose², Pratip Kumar Kundu³, Krishna Kumar Haldar4, Ardhendu Kumar Maji ${ }^{5}$ \\ ${ }^{1}$ Assistant Professor, Department of Microbiology, Murshidabad Medical College, Berhampore, West Bengal. \\ ${ }^{2}$ Associate Professor, Department of Microbiology, Murshidabad Medical College, Berhampore, West Bengal. \\ 3 Principal, Malda Medical College, West Bengal. \\ 4 Professor and HOD, Department of Microbiology, IQ City Medical College, Durgapur, West Bengal. \\ 5Reader, Department of Protozoology, School of Tropical Medicine, Kolkata.
}

\section{ABSTRACT}

\section{BACKGROUND}

Cryptosporidium is one of the most common intestinal pathogen throughout the world and is the most common waterborne pathogen associated with diarrhoea in AIDS patients. These parasites draw attention as an emerging pathogen with spread of AIDS pandemic. We undertook a study to find the prevalence of Cryptosporidiosis in HIV/AIDS and its correlation with CD4 count.

\section{METHODS}

In this study of one year duration 80 HIV seropositive patients were included (Fifty with diarrhoea and thirty without diarrhoea). Control group consisted of 80 HIV seronegative patients. Thorough history was taken for all enrolled subjects regarding name, age, sex, HIV status, presence/absence of diarrhoea, socio-economic status, source of drinking water and water for other purposes. For the study group history of the presenting complain, associated opportunistic infection, history of tuberculosis and other drug history was taken. A thorough history of the nature of diarrhoea was taken. CD4 count of the enrolled patients was carried out. Stool samples collected from each enrolled patient were examined microscopically by different methods for the presence of cryptosporidium and other ova, cysts and parasites.

\section{RESULT}

Infection was commoner in males being highest in the age group of 30-39 years; $72 \%$ acquired HIV infection heterosexually. Chronic diarrhoea was seen in $46.25 \%$ of HIV patients whose mean CD4 count was 176.7 cells/ $\mu$ L. The prevalence of Cryptosporidium in the study group was $12.5 \%$. In HIV positive diarrhoeal group, Cryptosporidium oocysts was found in $20 \%$ patients. Isospora was detected in one HIV patient. In the study population, $48.75 \%$ of patients had severe immunosuppression with CD4 count $\leq 200$ cells $/ \mu \mathrm{L} ; 70 \%$ of cryptosporidium isolation was from severely immunocompromised hosts with CD4 count $<100$ cells/ $\mu \mathrm{L}$. The duration of diarrhoea was inversely proportional to the CD4 count; $80 \%$ of patients suffering from cryptosporidiosis used municipality water for drinking.

\section{CONCLUSION}

Cryptosporidiosis is a well-known opportunistic infection in HIV patients, particularly those with chronic diarrhoea and the risk increases with a low CD4 count. However, sexual activities and use of improperly stored or treated drinking water is also a risk factor.

\section{KEYWORDS}

Cryptosporidium, Diarrhoea, HIV, CD4 Count.

HOW TO CITE THIS ARTICLE: Saha S, Bose M, Kundu PK, et al. Prevalence of cryptosporidiosis in HIV/AIDS patients in a tertiary care hospital in West Bengal. J. Evolution Med. Dent. Sci. 2016;5(76):5617-5622, DOI: 10.14260/jemds/2016/1268

\section{INTRODUCTION}

The waterborne pathogen Cryptosporidium is one of the most commonly identified intestinal pathogen throughout the world and is the most common waterborne pathogen associated with diarrhoea in people with AIDS. Genus Cryptosporidium causes Cryptosporidiosis. It belongs to phylum Apicomplexa, group Alveolata. Cryptosporidiosis is an important public health problem worldwide. Tyzzer in 1907 first recognised Cryptosporidium in gastric gland of

Financial or Other, Competing Interest: None.

Submission 15-08-2016, Peer Review 07-09-2016,

Acceptance 14-09-2016, Published 20-09-2016.

Corresponding Author:

Dr. Mohua Bose,

\#AL-210, Sector II, Salt Lake City,

Kolkata-700091, West Bengal.

E-mail: msdmicrobiology@gmail.com

DOI: $10.14260 /$ jemds $/ 2016 / 1268$

\section{(c) (i) $\odot$}

asymptomatic laboratory mice. ${ }^{1}$ Human cryptosporidiosis was first reported in 1976 by Nime. ${ }^{2}$ From 1976 to 1982, only eight cases of Cryptosporidium infection was reported in man, ${ }^{3}$ five of which were in immunosuppressed patients. Since then there has been a rapid increase in the number of such reports from almost all parts of the world. These parasites draw attention as an emerging pathogen with spread of AIDS pandemic.

Cryptosporidium infection of the gastrointestinal epithelium is self-limiting in immune competent persons but potentially life-threatening in immunocompromised persons, especially those with HIV/AIDS. Therapy of cryptosporidiosis is a challenge in immunocompromised patients. The host immune response is important in limiting the duration and severity of infection. Disease severity ranges from asymptomatic to severe, intractable diarrhoea depending upon the immune status, nutrition and age. It causes watery to mucoid diarrhoea with abdominal pain in normal hosts worldwide, persistent diarrhoea in children in developing 
countries and chronic diarrhoea in immunocompromised hosts including patients with AIDS.4,5,6 In the immunocompromised individuals, disease is not always restricted to gastrointestinal tract, but can disseminate to other sites including respiratory tract. The majority of human infections are caused by $C$. hominis and the cattle genotype of C. parvum. Other Cryptosporidium species that occasionally infect immunocompetent humans are C. meleagridis, C. felis and $C$. canis. Species that have been reported only in immunocompromised individuals are $C$. muris or $C$. andersoni.

Although, the natural history of parasitic diseases may be altered by co-infection of HIV, parasites may in turn facilitate the progression from asymptomatic infection to AIDS. Antiretroviral therapy has dramatically decreased the cryptosporidiosis prevalence and has a tremendous impact on diarrhoea related morbidity in HIV/AIDS patients in countries where antiretroviral agents are widely available. In AIDS patients, depletion of circulating $\mathrm{T}$ cells lead to increased susceptibility to opportunistic intestinal protozoal infections. Immunocompetent individuals can clear the parasites spontaneously, but AIDS patients (immunocompromised) fail to do so and suffer from prolonged diarrhoea.

Here, we undertook a study to find the prevalence of Cryptosporidiosis in HIV/AIDS patients in a Tertiary Care Hospital in West Bengal.

\section{AIMS AND OBJECTIVES}

1. To find out the prevalence of cryptosporidiosis among normal healthy subjects and HIV/AIDS patients.

2. To find out correlation between CD4 count and cryptosporidiosis.

\section{MATERIALS AND METHODS}

The present study is a cross-sectional study undertaken in the Department of Protozoology and Virology in the School of Tropical Medicine, Kolkata, from April 2010 to March 2011. Due clearance was obtained from the Institutional Ethical Committee. HIV positive patients in whom recent CD4 count was available and from whom informed consent could be obtained were included in the study. Patients taking antacids, non-absorbable anti-diarrhoeal preparations, mineral oils and other oily materials, patients suffering from malaria and with a history of taking antimalarial drugs within previous 2-3 weeks, those undergoing barium enema procedures within last one week and those undergoing invasive gall bladder investigations with dye within last three weeks were excluded from the study.

A total of 80 HIV seropositive patients attending the virology OPD of the School of Tropical Medicine, Kolkata and admitted in various wards of the adjoining Carmichael Hospital for Tropical Disease, Kolkata were included in the study and were selected as follows: Group 1: Consecutive fifty HIV seropositive patients with diarrhoea and Group 2: First thirty HIV seropositive patients without diarrhoea. Control subjects were recruited from two different sites (i) 50 patients having diarrhoea, but HIV seronegative were recruited from ID and BG Hospital, Beliaghata, Kolkata and (ii) First 30 patients without diarrhoea and HIV seronegative were recruited from the School of Tropical Medicine, Kolkata and adjoining Carmichael Hospital for Tropical disease, Kolkata. All study and control subjects were subjected to thorough history taking regarding name, age, sex, HIV status, presence/absence of diarrhoea, socio-economic status, source of drinking water and water for other purposes are noted in a designed proforma.

For the study group history of the presenting complaint, CD4 count, associated opportunistic infections, history of tuberculosis and other drug history was taken. A thorough history of the nature of diarrhoea was taken: frequency of stool (Times/day), duration (Days/months), presence of blood and mucous in stool and presence of nausea, vomiting, abdominal pain and fever. Three stool samples were collected from each enrolled patient and were examined in the Department of Protozoology by the following methods.

1. Direct wet mount preparation with saline and iodine.

2. Smear preparation after formal ether sedimentation and concentration.

3. Modified acid fast stain (Kinyoun) of the smear.

The preparations were examined for the presence of cryptosporidium and other ova, cysts and parasites.

CD4 count of the enrolled patients was carried out by FACS count (Becton Dickinson). Viral load was not measured due to economic constraints. Each time the participant provided a stool sample, the most recent CD4 count was recorded for analysis. Stool samples from patients without CD4 information were excluded from the analysis.

\section{RESULTS AND ANALYSIS}

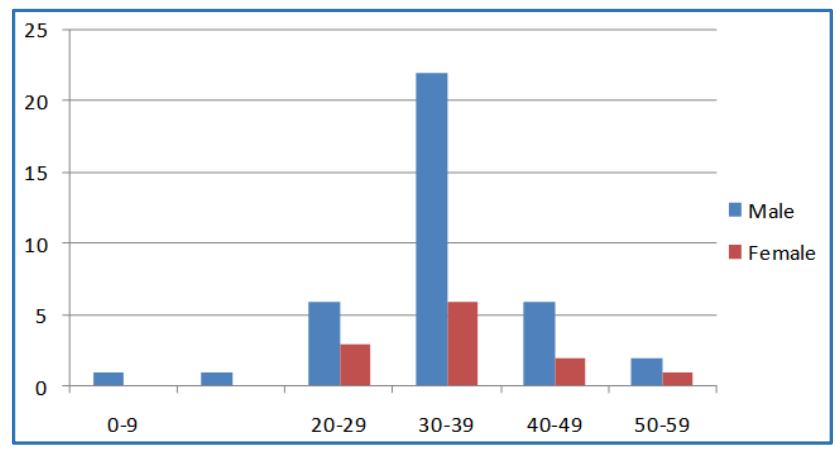

Fig. 1: Age \& Sex Distribution among HIV Positive Patients with Diarrhoea

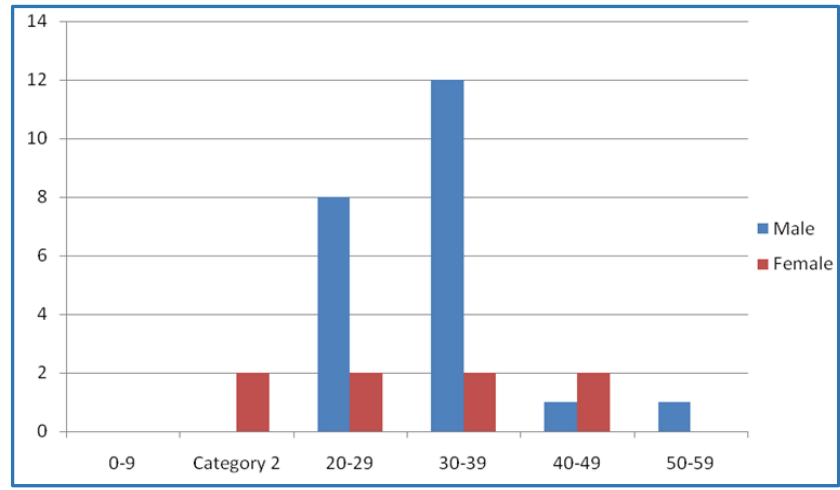

Fig. 2: Age \& Sex Distribution among HIV Positive Patients without Diarrhoea

The male:female ratio of the 80 HIV positive patients was $3: 1$. Most of the recruited patients were in the age group of 3039 years. 


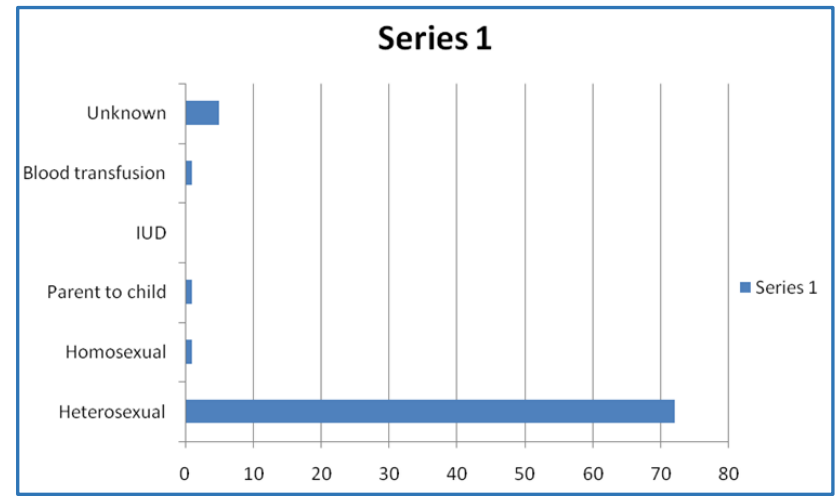

Fig. 3: Mode of Acquisition of HIV/AIDS Infection

$72 \%$ of the patients acquired HIV infection by heterosexual contact.

Stool Examination

\begin{tabular}{|c|c|c|c|c|}
\hline \multirow{1}{*}{} & \multicolumn{2}{|c|}{$\begin{array}{c}\text { HIV Positive } \\
\text { (Study Group) }\end{array}$} & \multicolumn{2}{|c|}{$\begin{array}{c}\text { HIV Negative } \\
\text { (Control Group) }\end{array}$} \\
\cline { 2 - 5 } & $\begin{array}{c}\text { With } \\
\text { Diarrhoea } \\
\text { (50) }\end{array}$ & $\begin{array}{c}\text { Without } \\
\text { Diarrhoea } \\
\text { (30) }\end{array}$ & $\begin{array}{c}\text { With } \\
\text { Diarrhoea } \\
\text { (50) }\end{array}$ & $\begin{array}{c}\text { Without } \\
\text { Diarrhoea } \\
\text { (30) }\end{array}$ \\
\hline $\begin{array}{c}\text { No. of } \\
\text { Patients } \\
\text { showing } \\
\text { Some } \\
\text { Parasites }\end{array}$ & 23 & 6 & 7 & 5 \\
\hline $\begin{array}{c}\text { No. of } \\
\text { Patients } \\
\text { showing } \\
\text { Cryptos- } \\
\text { poridium }\end{array}$ & 10 & - & 1 & - \\
\hline \multicolumn{5}{|c|}{ Table 1: Prevalence of Parasites in the } \\
Stool of the Study and Control Group \\
\hline
\end{tabular}

Therefore, the prevalence of Cryptosporidium in the study group was $12.5 \%$ (10 out of 80 ) and in the control group was only $1.25 \%$ ( 1 out of 80 ).

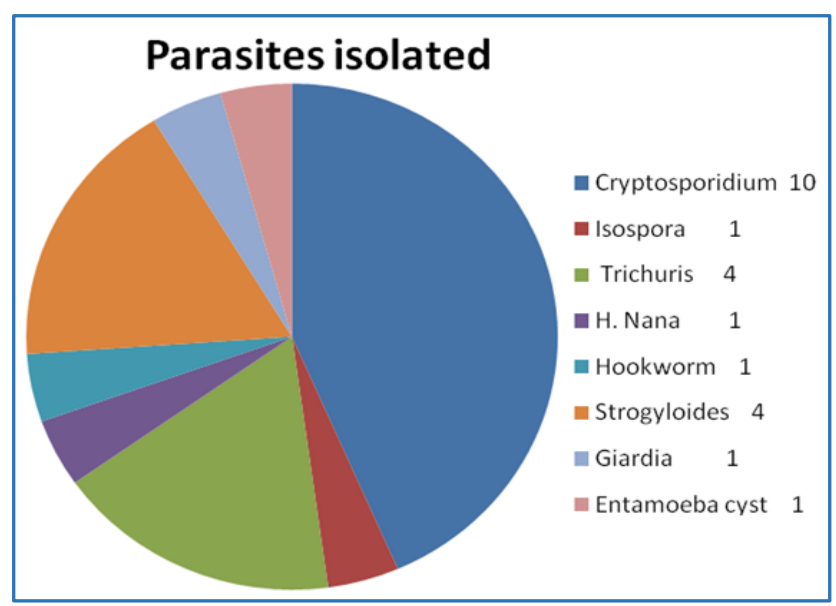

Fig. 4: Parasites Isolated in HIV Positive Patients with Diarrhoea

A variety of other parasites was also isolated from HIV positive patients with diarrhoea. Isospora was isolated from one patient.

\begin{tabular}{|c|c|c|c|c|}
\hline $\begin{array}{c}\text { HIV } \\
\text { Status }\end{array}$ & $\begin{array}{c}\text { Acute } \\
\text { Diarrhoea }\end{array}$ & $\begin{array}{c}\text { Chronic } \\
\text { Diarrhoea }\end{array}$ & $\begin{array}{c}\text { Persistent } \\
\text { Diarrhoea }\end{array}$ & Total \\
\hline $\begin{array}{c}\text { HIV } \\
\text { Positive }\end{array}$ & 9 & 37 & 4 & 50 \\
\hline $\begin{array}{c}\text { HIV } \\
\text { Negative }\end{array}$ & 28 & 10 & 12 & 50 \\
\hline \multicolumn{2}{|c|}{$\begin{array}{c}\text { Table 2: The Presentation of Diarrhoea in the } \\
\text { Study and the Control Group was as Follows }\end{array}$} \\
\hline
\end{tabular}

The mean CD4 count in HIV positive patients suffering from acute diarrhoea was 295.5 cells $/ \mu \mathrm{L}$, while those suffering from chronic diarrhoea was 176.7 cells $/ \mu \mathrm{L}$.

\begin{tabular}{|c|c|c|c|}
\hline $\begin{array}{c}\text { CD4 } \\
\text { Range } \\
(\text { Cells/ } \boldsymbol{\mu L})\end{array}$ & $\begin{array}{c}\text { HIV Infected } \\
\text { with } \\
\text { Diarrhoea } \\
(\mathbf{N = 5 0 )}\end{array}$ & $\begin{array}{c}\text { HIV Infected } \\
\text { Without Diarrhoea } \\
\mathbf{( N = 3 0 )}\end{array}$ & $\begin{array}{c}\text { \% the } \\
\text { Study } \\
\text { Group }\end{array}$ \\
\hline $0-199$ & 30 & 9 & $48.75 \%$ \\
\hline $200-500$ & 18 & 17 & $43.75 \%$ \\
\hline$>500$ & 2 & 4 & $7.5 \%$ \\
\hline \multicolumn{3}{|c|}{$\begin{array}{c}\text { Table 3: Distribution of the CD4 Count } \\
\text { in the Study Group was as Follows }\end{array}$} \\
\hline
\end{tabular}

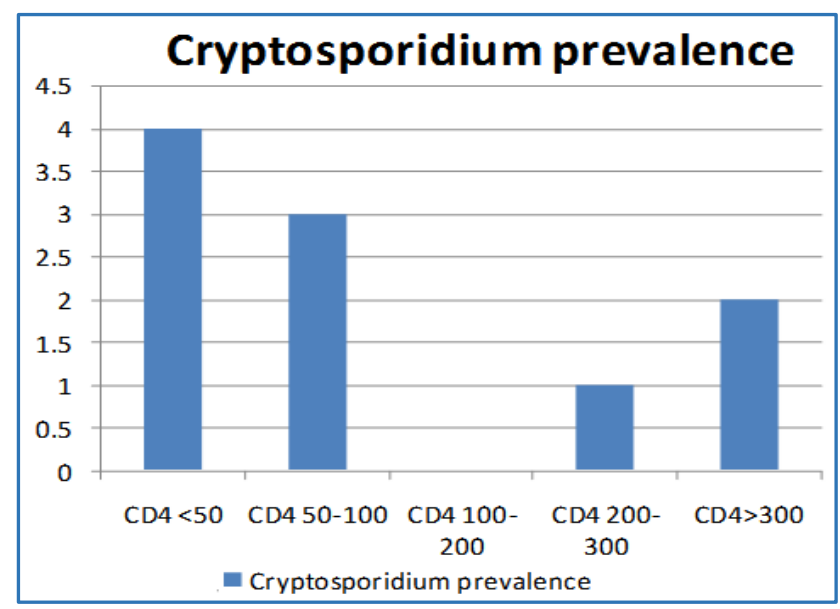

Fig. 5: Correlation between CD4 Level and cryptosporidium in HIV Positive Patients with Diarrhoea

7 out of 10 Cryptosporidium positive patients had a CD4 count $<100$ cells $/ \mu \mathrm{L}$.

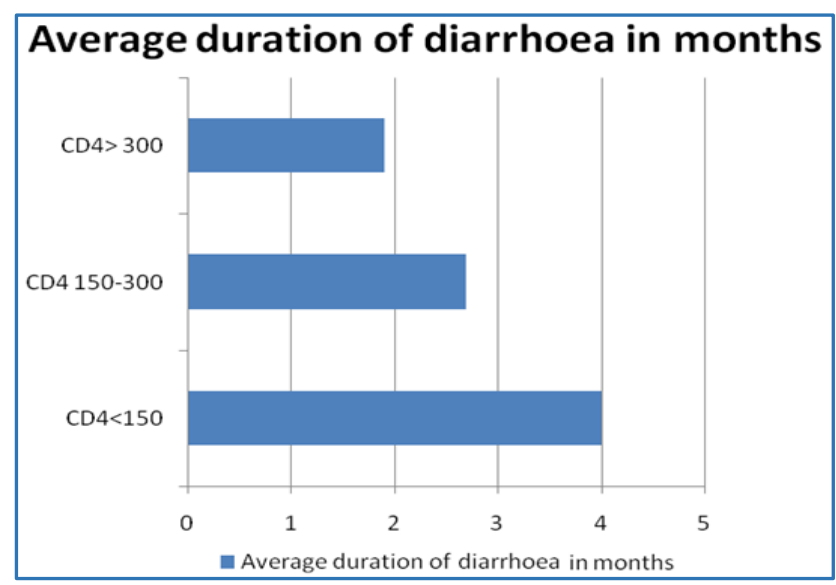

Fig. 6: Correlation between the Duration of Diarrhoea (in months) and CD4 Level in Cryptosporidiosis Patients

The average duration of diarrhoea in HIV patients with CD 4 count $<150$ cells/ $\mu \mathrm{L}$ was 4 months, whereas that in HIV patients with CD 4 count $>300$ cells $/ \mu \mathrm{L}$ was 1.9 months. The duration of diarrhoea was more in the lower $\mathrm{CD} 4$ range. 


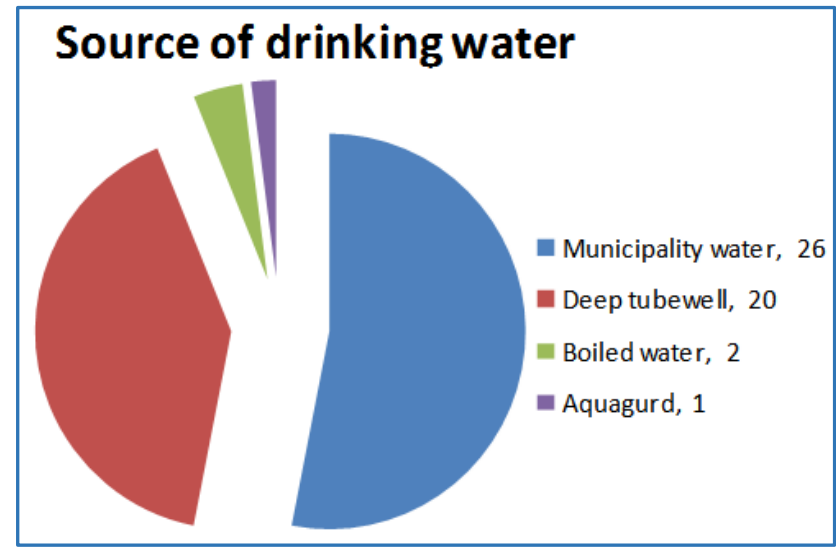

Fig. 7: Source of Drinking Water of the HIV Positive Patients with Diarrhoea

Most of the HIV positive patients with diarrhoea used municipality water for drinking purpose.

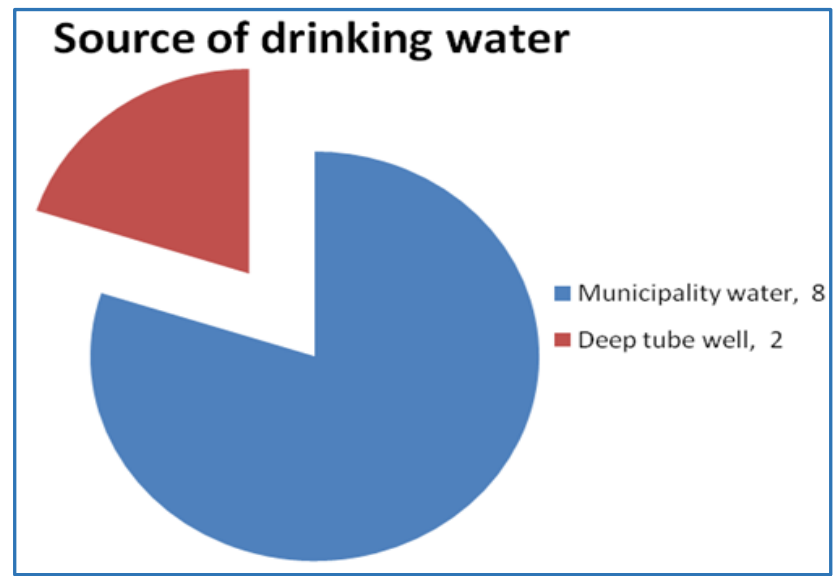

Fig. 8: Source of Drinking Water of the HIV Positive Patients with Diarrhoea showing Cryptosporidium in Stool

8 of the 10 patients showing Cryptosporidium in stool used Municipality water as a source of drinking water.

\section{DISCUSSION}

The present cross-sectional study was designed to have a comprehensive idea of the prevalence of cryptosporidiosis in HIV infected persons reporting at the School of Tropical Medicine, Kolkata, with an aim to find out correlation between CD4 count and cryptosporidiosis.

In the present study, infection in the study group was commoner in males with a highest rate in the age group of 30 39 years (Fig. $1 \& 2$ ). This is similar to a study conducted by Aziz A et al in Jaipur where the male-to-female ratio was 3:1, $69.2 \%$ of the study population were males and $30.8 \%$ were females and most patients were in the age group of 31-40.7 In our study, $72 \%$ acquired HIV infection heterosexually (Fig. 3). Rest of the patients acquired HIV by other modes of transmission. Sexual behaviour is a known risk factor for acquiring cryptosporidiosis. Chances of cryptosporidiosis were more in oro-anal sexual practices.

Present study showed that $80 \%$ of patients suffering from cryptosporidiosis used municipality (Fig. 8) water as a source of drinking water. Municipality used ground water or treated water for supply to the locality. Efficacy of water treatment plants depend on the source of water, temperature of treatment plant, amount of disinfectant used, etc. Post treated water can also be contaminated due to leak or break in supply system. In homes, water can also be contaminated due to inappropriate storage methods. ${ }^{8}$

The present study had the aim to isolate Cryptosporidium associated with diarrhoea in both HIV positive and HIV negative patients. In HIV infected diarrhoea group, 9 patients presented with acute diarrhoea and 37 patients (46.25\%) presented with chronic diarrhoea (Table 2). In HIV positive diarrhoeal group, Cryptosporidium oocysts were found in the stool of 10 patients $(20 \%)$, whereas in the non-diarrhoeal group no Cryptosporidium was isolated. In HIV negative diarrhoeal group Cryptosporidium oocysts was found in one patient (2\%). However, the overall prevalence of Cryptosporidium in the study group was $12.5 \%$ (10 out of 80 ) and in the control group was only $1.25 \%$ (1 out of 80 ) (Table 1).

In Indian study, Cryptosporidium has been isolated from all parts of the country in stool samples of HIV infected persons. In a study in Southern India, Cryptosporidium has been isolated in Chennai as $13.72 \%$ and $8 \%$ in diarrhoeal and non-diarrhoeal patients respectively. ${ }^{9}$ In Northern India isolation rate in HIV infected diarrhoeal patients in two different studies was $11 \%^{10}$ by Prasad et al and $10.8 \%{ }^{11}$ by Mohandas et al. In Mumbai, Joshi et al isolated Cryptosporidium in $8.5 \%$ cases. ${ }^{12}$ Some higher rates of isolation have been found in some studies like in Karnataka $46.7 \%, 13$ in asymptomatic HIV infected individuals by Anand et al as $65.8 \%,{ }^{14}$ by Panda et al as $23 \%{ }^{15}$ and by Agarwal et al as $33.3 \% .16$ In world literature, isolation of cryptosporidium from HIV infected patients has been found to vary in different countries like $12.8 \%$ in Thailand, ${ }^{17} 10.5 \%$ in South Korea, ${ }^{18}$ $41.3 \%$ in Venezuela, ${ }^{19} 39.7 \%$ in Epthiopia, ${ }^{20} 1.5 \%$ in Iran, ${ }^{21}$ $10.4 \%$ in Bogota-Cambodia, 22 3\% in Netherland 23 and $15-16 \%$ in Maryland USA. 24,25

In our study the rates are much higher in the diarrhoeal group (20\%), while no Cryptosporidium was isolated in the non-diarrhoeal group. In our study, the prevalence of Cryptosporidiosis in HIV infected patients $(12.5 \%)$ agrees with results by Prasad et $\mathrm{al}^{10}$ and Mohandas et $\mathrm{al}^{11}$ and also with study reports Thailand, South Korea and Cambodia. ${ }^{17,18,22}$

However, the prevalence is lower than the studies done in other parts of the country. This could be probably due to use of more sensitive detection methods in other studies. Another most probable explanation for the low count may be the low prevalence of cryptosporidium in this locality.

Isospora belli, another opportunistic coccidian protozoan was detected in $2 \%$ of HIV infected diarrhoeal patients in our study (Fig. 4). This was consistent with the study by Mohandas et al, showing a detection rate of $2.5 \%$ in HIV seropositive patients. ${ }^{11}$

In the present study, CD4 cells were estimated for HIV infected patients. It ranged from 22 cells $/ \mu \mathrm{L}$ to 847 cells $/ \mu \mathrm{L}$ with a median of 57.5 cells $/ \mu \mathrm{L}$ in diarrhoeal patients. Among them 39 patients out of $80(48.75 \%)$ in the study population had severe immunosuppression with CD4 count $\leq 200$ cells $/ \mu \mathrm{L}$, while 35 patients that is $43.75 \%$ had moderate immunosuppression with CD4 count between 201 to 499 cells/ $\mu$ L. Only 6 patients (7.5\%) had mild disease with CD 4 count $\geq 500$ cells $/ \mu \mathrm{L}$ (Table 3 ); $70 \%$ (7 out of 10 ) of cryptosporidium isolation was from severely immunocompromised hosts with CD4 count was less than 100 cells $/ \mu \mathrm{L}$ (Fig. 5). This finding is consistent with a study 
conducted by Tuli L et al, who concluded that the maximum isolation of Cryptosporidium (66.6\%) was from HIV patients with CD 4 count $<200$ cells $/ \mu L^{26}$ Dwivedi et al ${ }^{27}$ observed that infection rate was $55.6 \%$ in HIV infected diarrhoeal patients with single parasitic infection who had a mean CD4 count of 161 cells $/ \mu \mathrm{L}$. Sarfati et al found the prevalence of opportunistic protozoa (Mostly Cryptosporidium, Isospora and microsporidium) was $32 \%$ in patients with less than 50 CD4 cells/ $\mu \mathrm{L}$ in Cameroon. ${ }^{28}$ In our study, the CD4 levels were inversely proportional to the duration of diarrhoea. The duration of diarrhoea increased with the decrease in the CD4 count. Similar results were also obtained by Tuli L et al. ${ }^{26}$ In our study, the average duration of diarrhoea in HIV patients with CD4 count $<150$ cells/ $\mu \mathrm{L}$ was 4 months, whereas that in HIV patients with CD4 count $>300$ cells $/ \mu \mathrm{L}$ was 1.9 months (Fig. 6).

HIV infection causes a gradual decline in the peripheral CD4 helper lymphocyte count. These lymphocytes are part of the body's immune system and play a key role in cell mediated immunity. But as HIV destroys these lymphocytes, HIVinfected patients become predisposed to opportunistic infections. As their CD4 lymphocyte count fall below 200 cells $/ \mu \mathrm{L}$, they become prone to a wide range of opportunistic infection including cryptosporidiosis.

This study had some limitations: Light microscope was used in this study for detection of parasites in stool, which is not as sensitive as modern methods like polymerase chain reaction which is not available in our institute. Also this study does not differentiate between species, because of the dearth of sensitive parasites detection techniques like polymerase chain reaction technique, Isoenzyme analysis and antigen detection techniques.

\section{CONCLUSION}

It is well known that immunocompromised patients infected with HIV are at higher risk for Cryptosporidiosis and that carriage of the parasite is associated with diarrhoeal disease in most cases. There is good evidence that risk of fecal carriage of cryptosporidiosis is directly related to the CD4 count. However, behavioural factors such as sexual activity (Most particularly having multiple sexual partners and engaging in oro-anal sex) also play a significant role. Prevalence was higher in patients using municipality water for drinking. Therefore, to reduce the prevalence of coccidian parasites among HIV infected persons practicing safe sex should be encouraged. Also maintenance of proper drinking water quality with appropriate storage facilities, proper sanitation and hygiene (Particularly washing of hands) should be practiced to reduce the disease burden in the community.

\section{ACKNOWLEDGEMENT}

We extend our sincere thanks to all faculty members, technical and non-technical and non-technical staff of Department of Microbiology, School of Tropical Medicine, for all the support given by them to carry out this work.

\section{REFERENCES}

1. Tyzzer EE. A sporozoan found in peptic glands of the common mouse. Proc Soc Exp Bio Med 1907;5:12-3.

2. Nime FA, Burek JD, Page DL, et al. Acute enterocolitis in a human being infected with the protozoan cryptosporidium. Gastroenterology 1976;70(4):592-8.
3. World Health Organization. Diarrhoeal disease control programme: La Cryptosporidiose. Geneve: Organisation mondiale de la Sante CDD/87.3 1987.

4. Kosek M, Alcantara C, Lima AA, et al. Cryptosporidiosis: an update. Lancet Infect Dis 2001;1(4):262-9.

5. Chen XM, Keithly JS, Paya CV, et al. Cryptosporidiosis. N Engl J Med 2002;346(22):1723-31.

6. Bushen OY, Lima AA, Guerrant RL. Cryptosporidiosis. In: Guerrant RL, Walker DH, Weller PF, eds. Tropical infectious diseases. Principle, pathogens and practice. Philadelphia: Churchill Livingstone 2006:1003-14.

7. Vyas N, Pathan N, Aziz A. Enteric pathogens in HIVpositive patients with diarrhoea and their correlation with cd4+t-lymphocyte counts. Tropical Parasitology 2012;2(1):29-34.

8. Medema G. EHC cryptosporidium draft 2.1. WHO guideline for drinking water quality. 2006.

9. Ajjampur RSS, Asirvatham JR, Muthusamy D, et al. Clinical features and risk factors associated with cryptosporidiosis in HIV infected adults in India. Indian J Med Res 2007;126(6):553-7.

10. Prasad KN, Nag VL, Dhole TN, et al. Identification of enteric pathogens in HIV positive patients with diarrhea in northern India. J Health Popul Nutr 2000;18(1):23-6.

11. Mohandas K, Sehgal R, Sud A, et al. Prevalence of intestinal parasitic pathogens in HIV seropositive individuals in northern India. Jpn J of Inf Dis 2002;55(3):83-4.

12. Joshi M, Chowdhury AS, Dalal PJ, et al. Parasitic diarrhoea in patients with AIDS. Natl Med J of India 2002;15(2): 72-4.

13. Ballal M, Prabhu T, Chandran A, et al. Cryptosporidium and isospora belli diarrhoea in immunocompromised hosts. Indian J Cancer 1999;36(1):38-42.

14. Anand L, Dhanachand C, Brajachand N. Prevalence and epidemiologic characteristics of opportunistic and nonopportunistic intestinal parasitic infections in HIV positive patients in Manipur. J Commun Dis 1998;30(1):19-22.

15. Panda S, Kamei G, Pamei M. Clinical features of HIV infections in drug users in Manipur. Natl Med J India 1994;7(6):267-9.

16. Agarwal AK, Singh NY, Devi LB, et al. Clinical features \& HIV progression as observed longitudinally in a cohort of injecting drug users in Manipur. The Indian Journal of Medical Research 1998;108:51-7.

17. Saksirisampant W, Eampokalap B, Rattanasrithong M, et al. A prevalence of cryptosporidium infections among Thai HIV-infected patients. J Med Assoc Thai 2002;85 (Suppl 1):S424-8.

18. Guk SM, Seo M, Park YK, et al. Parasitic infections in HIVinfected patients who visited Seoul national university hospital during the period 1995-2003. The Korean Journal of Parasitology 2005;43(1):1-5.

19. Chacin-Bonilla L, Guanipa N, Cano G, et al. Cryptosporidiosis among patients with acquired immunodeficiency syndrome in Zulia State, Venezuela. Am J Trop Med Hyg 1992;47(5):582-6.

20. Mengesha B. Cryptosporidiosis among medical patients with the acquired immunodeficiency syndrome in Tikur Anbessa Teaching Hospital, Ethiopia. East Afr Med J 1994;71(6):376-8. 
21. Zali MR, Mehr AJ, Rezaian M, et al. Prevalence of intestinal parasitic pathogens among HIV-positive individuals in Iran. Jpn J Infect Dis 2004;57(6):268-70.

22. Florez AC, Garcia DA, Moncada L, et al. Prevalence of microsporidia and other intestinal parasites in patients with HIV infection, Bogota, 2011. Biomedica 2003;23(3):274-82.

23. Cranendonk RJ, Kodde CJ, Chipeta D, et al. Cryptosporidium parvum and isospora belli infections among patients with and without diarrhea. East Afr Med J 2003;80(8):398-401.

24. Smith PD, Lane HC, Gill VJ, et al. Intestinal infection in patients with the aquired immunodeficiency syndrome (AIDS). Etiology and response to therapy. Annals of Internal Medicine 1998;108(3):328-33.

25. Sauda FC, Zamarioli LA, Filho EW, et al. Prevalence of cryptosporidium sp. and isospora belli among AIDS patients attending santos reference center for AIDS, São Paulo, Brazil. J Parasitol 1993;79(3):454-6.
26. Tuli L, Gulati AK, Sundar S, et al. Correlation between cd4 counts of HIV patients and enteric protozoan in different seasons-an experience of a tertiary care hospital in Varanasi (India). BMC Gastroenterology 2008;8:36.

27. Dwivedi KK, Prasad G, Saini S, et al. Enteric opportunistic parasites among HIV infected individuals: associated risk factors and immune status. Japanese Journal of Infectious Diseases 2007;60(2-3):76-81.

28. Sarfati C, Bourgeois A, Menotti J, et al. Prevalence of intestinal parasites including microsporidia in human immunodeficiency virus-infected adults in Cameroon: a cross-sectional study. American Journal of Tropical Medicine and Hygiene 2006;74(1):162-4. 